\title{
PROTECTING A CLIENT'S CONFIDENCES: RECENT DEVELOPMENTS IN PRIVILEGED COMMUNICATION BETWEEN ATTORNEYS AND ACCOUNTANTS
}

\author{
Noah P. Barsky, ${ }^{*}$ Anthony H. Catanach, Jr., ${ }^{* *}$ Ilya A. Lipin ${ }^{* * *}$ and \\ Shelley C. Rhoades-Catanach ${ }^{* * *}$
}

\begin{abstract}
The attorney-client privilege is one of the foundations of our jurisprudence. Originally, designed to prevent attorneys from testifying against their clients, the privilege eventually evolved to reflect legal, societal, and financial complexities. This privilege depends on full disclosure and open communication between attorney and the client in order to provide competent and adequate representation. Today, attorneys often require and rely on expert guidance of accountants for various issues pertaining to litigation and transactional work.

This article illustrates how the recent cases of Commissioner v. Comcast Corp. and United States v. Textron affect privileged communications in complex tax and transactional matters between attorneys and accountants retained for the purposes of client representation. The article also offers guidance on how to preserve privilege in communication between attorneys and accountants as waiver of such privilege may have significant and costly implications. At conclusion, unresolved issues pertaining to privileged communication are discussed and solutions are offered.
\end{abstract}

\section{Costly Implications of Privilege Breach}

Today's complex financial and tax transactions almost always require advice and assistance of attorneys, accountants, and tax professionals. Such teams of experts are often necessary to translate and interpret increasingly

* Noah P. Barsky Ph.D., CPA, CMA is an associate professor at the Villanova School of Business.

** Anthony H. Catanach, Jr. Ph.D., CPA, CMA is an associate professor at the Villanova School of Business and the Cary M. Maguire Fellow at the American College Center for Ethics in Financial Services.

*** Ilya A. Lipin J.D., LL.M. is a Philadelphia tax attorney and a Graduate Fellow at the Villanova School of Business.

**** Shelley C. Rhoades-Catanach, Ph.D., CPA is an associate professor at the Villanova School of Business. 
complex tax laws. ${ }^{1}$ Complex tax legislation, fluctuating and numerous tax rates and tax bases, and the number of special tax provisions and exceptions to those provisions contribute to the difficulty of tax practice and planning. ${ }^{2}$ Absent a team effort, even experienced attorneys may have to proceed into multifaceted transactions without a thorough understanding of their consequences, thus exposing their clients to potential and significant risks.

Open communications, protected by privilege, are a key to successful implementation of a client's goals. In order to obtain the utmost advantage from communications with accountants, attorneys must be able to have open conversations without fear that these discussions may at a future time become available to discovery by third parties, such as the Internal Revenue Service ("IRS"), State and Local Tax ("SALT") agencies, and other governmental bodies. If clients perceive that privilege laws do not protect their communications with attorneys, clients will be discouraged from openly conferring with their counsel, which inevitably will result in less effective legal compliance. ${ }^{3}$

Recent Comcast and Textron decisions raise important new issues and concerns for attorneys and their clients about the waiver and inapplicability of corporate taxpayers' privileges during complex transactional matters or compliance with federal and state laws and regulations. ${ }^{4}$ Communication of sensitive and privileged information from attorneys to accountants is necessary to construct a transaction or to comply with reporting requirements. The Comcast and Textron decisions suggest that such communication may result in waiving all available privileges. ${ }^{5}$

Disclosure of internal and privileged corporate information to taxing authorities diminishes the preventative and strategic roles of a public company's in-house counsel ${ }^{6}$ and undermines corporate tax planning. When the taxing authorities can obtain access to work papers and other privileged

1. United States v. Kovel, 296 F.2d 918, 921 (2d Cir. 1961).

2. Kelly Edmiston, Shannon Mudd \& Neven Valev, Tax Structures and FDI: The Deterrent Effects of Complexity and Uncertainty, 24 FISCAL STUD. 341, 343-44 (2003).

3. Laura Stein, Waiver of the Attorney-Client Privilege: A Balanced Approach (2006), http://www.wlf.org/upload/thornburgh.pdf.

4. Jocelyn Allison, U.S. v. Textron Raises Concern Over Work Product, Law360.com, Oct. 9 , 2009, http://www.law360.com/articles/123606 (stating the holding in Textron is "important to the IRS and companies that file audited financial statements").

5. In this context, the available privileges include attorney-client privilege, accountant-client privilege, work-product doctrine, and tax-practitioner privilege.

6. James Hamilton, Corporate Counsel Group Assails First Circuit Tax Audit Work Papers Ruling, PCAOB REP., Sept. 22, 2009, at 4. 
information, they can determine where the taxpayer believes its asserted tax position is weak and amounts reserved to pay the tax if litigation ensues. ${ }^{7}$ This information may allow the IRS and SALT agencies to pursue and challenge any transaction where there may be a chance of tax avoidance planning, even if permitted by the current statutory regime. The disclosure of privileged documents may provide the taxing authorities with a roadmap for additional audits. These new developments also raise concern of whether the IRS will abandon or modify its policy of restraint on limiting its future work papers request to taxpayers engaging in listed transactions. ${ }^{8}$

The Textron decision specifically suggests that a company's FIN 48 work papers $^{9}$ are no longer fully protected and immune from discovery by the taxing authorities. ${ }^{10}$ As FIN 48 work papers contain sensitive information about tax effects on which the corporate position may not be certain, the content of these documents is enticing to IRS and SALT auditors and compliance officers. $^{11}$ The Comcast decision reminds practitioners of limitations of current privilege law pertaining to communication between attorney and external accountants and shows that SALT authorities are willing to challenge complex corporate transactions to bolster state revenue. ${ }^{12}$ Comcast also is consistent with the trend by SALT authorities of auditing multi-state

7. Amier Efrati, Ruling in Tax-Auditing Case Puts Corporations on Edge, Wall St. J., Aug. 20, 2009, at A9, available at http://online.wsj.com/article/SB125072397055744533.html.

8. En Banc First Circuit Rules For IRS In Textron Accrual Disclosures, Standard Fed. Tax ReP. 1-2, Aug. 2009, at 1, 2. See also Keith J. Anzel, Cheryl Claybough, Chris Oates, David Robison, \& Michael J. McGoldrick, Session 11: Risk-Based Approach to Large Corporate Audits, TAXES-THE TAX MAG., June 2009, at 125, 126 (stating that the IRS continues to evaluate the policy of restraint as tax accrual work papers during an audit would help to facilitate and accelerate the resolution process).

9. Financial Accounting Standards Board, Interpretation No. 48, Accounting for UnCertainty in InCOMe TAXes, an Interpretation of FASB Statement No. 109 (prescribing a recognition threshold and measurement attribute for the financial statement recognition and measurement of a tax position taken or expected to be taken in a tax return and providing guidance on derecognition, classification, interest and penalties, accounting in interim periods, disclosure, and transition).

10. Robert W. Wood \& Alfred K. Leong, Tax Accrual Workpapers May Be Privileged, M \& A TAX Rep., Nov. 2007, at 3-5. See also Jean Pawlow \& Kevin Spencer, Adrift In a Sea of Uncertainty: Tax Accrual Workpapers Are Work-Product... But Showing Them to Your Auditor May Waive the Protection, Tax Executive, Jan.-Feb. 2009, at 33, 37 (stating that "[g]iven the First Circuit's holding on waiver, it is unclear whether disclosing a FIN 48 opinion to your independent auditors will waive the work product privilege").

11. See Philip C. Cook, Practical Suggestions To Enhance The Work Product Protection of Client Tax Accrual and FIN 48 Workpapers, PraC. TAX LAW., Feb. 2009, at 33.

12. Scott Edwards, MASSACHUSETTS: Massachusetts High Court Applies Broad 'Because of' Expected Litigation Test to Exclude Accountant's Memos Under Work-Product Doctrine, J. OF Multistate TaX'N \& Incentives, July 2009, at 36-38. 
structures and transactions more aggressively, which inevitably leads to disclosure of work papers and related tax planning advice. ${ }^{13}$

\section{Privileges}

By their nature, all privileges limit access to the "complete" truth. ${ }^{14}$ However, almost all privileges are limited and restricted either by definition, exceptions to the definition, or by other specific limitations. Professionals commonly assert privileges such as the attorney-client privilege, work-product doctrine, and tax practitioner privilege during litigation when the opposing side requests disclosure of private information and documents. Knowledge of when to exercise the privilege and of all applicable exceptions will allow practitioners to serve in clients' best interests and avoid unnecessary legal exposure.

\section{A. Attorney-Client Privilege}

The attorney-client privilege is one of the foundations of our jurisprudence. The attorney-client privilege protects all confidential communications between a client and its attorney undertaken to obtain legal advice. ${ }^{15}$ It is well established, appearing first in the sixteenth century, ${ }^{16}$ and is often recognized as one of the oldest confidential communications privileges known to the common law. ${ }^{17}$ It is also considered to be a "bedrock of the client's rights to effective counsel and confidentiality" in obtaining legal advice..$^{18}$ In the federal system, the attorney-client privilege is governed by the principles of the common law. ${ }^{19}$ Under the common law, the important element of the attorney-client privilege is "whether the communication between the client and the attorney is made in confidence of the relationship and under circumstances from which it may reasonably be assumed that the communication will remain in confidence." 20

13. See Cook, supra note 11 , at 33 .

14. 8 J. Wigmore, Evidence $§ 2291$ (McNaughton Rev. 1961).

15. Suffolk Constr. Co. v. Div. of Capital Asset Mgmt., 870 N.E.2d 33, 37 (Mass. 2007).

16. P.R. Rice, Attorney-Client Privilege in the United States $\S 1: 1$, at 6 (2d ed. 1999).

17. Upjohn Co. v. United States, 449 U.S. 383, 389 (1981).

18. Karen J. Mathis, President of American Bar Association, Statement Before the U.S. Senate Judiciary Committee, A.B.A., Sept. 12, 2006, available at http://lawprofessors.typepad.com/ whitecollarcrime_blog/files/attyclientprivissueabatestimonytosenjudcommkarenmathissept122006.pdf.

19. FED. R. EvID. 501.

20. United States v. Lopez, 777 F.2d 543, 552 (10th Cir. 1985) (citing Wilcoxon v. United States, 
The classic formulation of the attorney-client privilege states that where legal advice is sought, the communication relating to that purpose made in confidence by the client to attorney is permanently protected from disclosure, unless the privilege is waived. ${ }^{21}$ The attorney-client privilege enables clients to fully disclose to their attorney all relevant facts, no matter how embarrassing or damaging these facts might be, so that the attorney may render fully informed legal advice. ${ }^{22}$ To be considered privileged, the information contained within the communication between attorney and client need not itself be confidential; rather, the communication must be made in confidence. $^{23}$

For the purposes of the privilege, an attorney is any person whom the client reasonably believes to be a lawyer ${ }^{24}$ authorized to practice law in any state or nation. ${ }^{25}$ The attorney-client privilege may be asserted even if the communication is not privileged in the jurisdiction where the attorney is licensed. ${ }^{26}$ The privilege applies to individuals and corporations. ${ }^{27}$ The attorney-client privilege is extended to individuals employed by the lawyer to assist in rendering professional legal services. ${ }^{28}$ Thus, this principle applies to

231 F.2d 384, 386 (10th Cir. 1956)).

21. Comm'r v. Comcast Corp., 901 N.E.2d 1185, 1194 (Mass. 2009) (quoting Wigmore, 8 J. Wigmore, EvidENCE $§ 2292$ (McNaughton Rev. 1961)) (stating “(1) [w] here legal advice of any kind is sought (2) from a professional legal adviser in his capacity as such, (3) the communications relating to that purpose, (4) made in confidence (5) by the client, (6) are at his instance permanently protected (7) from disclosure by himself or by the legal adviser, (8) except the protection be waived"). This formulation has been frequently used by federal courts.

22. Suffolk Constr. Co. v. Div. of Capital Asset Mgmt., 870 N.E.2d 33, 38 (Mass. 2007). See also United States v. Ackert, 169 F.3d 136, 139 (2d Cir. 1999) (quoting Fisher v. United States, 425 U.S. 391, 403 (1976)) (stating the purpose of the privilege is "to encourage clients to make full disclosure to their attorneys"); Hatton v. Robinson, 31 Mass. 416, 422 (1834) (stating the attorney-client privilege exists to enable the attorney to "successfully to perform the duties of his office").

23. Comcast, 901 N.E.2d at 1196.

24. United States v. Boffa, 513 F. Supp. 517, 523 (D. Del. 1981) (citing Wigmore, 8 J. Wigmore, EVIDENCE $§ 2302$ (McNaughton Rev. 1961)) (stating "the privilege is extended to those who make confidential communications to an individual in the genuine, but mistaken, belief that he is an attorney"). The reasonableness depends on circumstances of each case.

25. 3 Jack B. Weinstein \& Joseph M. McLaughlin, Weinstein’s Federal Evidence $§ 503$ (Joseph M. McLaughlin ed., 2d ed. 1997).

26. See id. at $\S 503.12$.

27. Gretchen Eoff, Losing the War on Attorney-Client Privilege: Viewing the Selective Waiver Quagmire Through the Tenth Circuit's In re Qwest Communications International, 75 Def. Couns. J. 79, 81 (2008).

28. See In re The Inv. Bankers, Inc., 30 B.R. 883, 886 (Bankr. D. Colo. 1983). 
the lawyer's staff, consultants, or other agents employed for assistance with legal services. ${ }^{29}$

At times, the attorney-client privilege conflicts with society's interest of full and complete disclosure, but it is a sacrifice society must absorb to offer justice for every citizen. ${ }^{30}$ This impediment to client's communication with the attorney promotes greater public interest in the observance of law and administration of justice. ${ }^{31}$ However, this is balanced by the attorney-client privilege being strictly and narrowly construed. ${ }^{32}$ When the taxpayer's information is being withheld from the government in a tax enforcement proceeding, the narrow construction of privilege is particularly appropriate. ${ }^{33}$

The party asserting the attorney-client privilege has the burden of establishing that attorney-client privilege applies to the communication or documents requested. ${ }^{34}$ The burden includes proving the existence of the attorney-client relationship and other elements such as: (1) the communications were received from a client during the course of the client's search for legal advice from the attorney in his or her capacity as such; (2) the communications were made in confidence; and (3) the privilege as to these communications has not been waived. ${ }^{35}$

29. Weinstein \& McLaughlin, supra note 25, at $\S 503.01$ (regarding U.S. Supreme Court Standard 503). Note that Supreme Court standards are not part of the Federal Rules of Evidence, but have been relied upon and cited by other courts. See United States v. Spector, 793 F.2d 932, 938 (8th Cir. 1986).

30. In re John Doe Grand Jury Investigation, 408 Mass. 480, 482 (1990).

31. Upjohn, 449 U.S. at 389. See also Hanover Ins. Co. v. Rapo \& Jepsen Ins. Servs., Inc., 870 N.E.2d 1105, 1111 (Mass. 2007) (quoting In re A Grand Jury Investigation, 723 F.2d 447, 451 (Mass. 2002), cert. denied, 467 U.S. 1246 (1984); Commonwealth v. Goldman, 480 N.E.2d 1023 (Mass. 1985), cert. denied, 474 U.S. 906 (1985)) ("The attorney-client privilege is so highly valued that, while it may appear "to frustrate the investigative or fact-finding process ... [and] create an inherent tension with society's need for full and complete disclosure of all relevant evidence during implementation of the judicial process, '... it is acknowledged that the social good derived from the proper performance of the functions of lawyers acting for their clients ... outweigh[s] the harm that may come from the suppression of the evidence.").

32. United States v. Ruehle, 583 F.3d 600, 609 (9th Cir. 2009). See also Weil v. Inv./Indicators, Res. \& Mgmt., Inc., 647 F.2d 18, 24 (9th Cir. 1981) (stating "[b]ecause it impedes full and free discovery of the truth, the attorney-client privilege is strictly construed"); In re Horowitz, 482 F.2d 72, 81 (2d Cir. 1973) (“[T]he privilege stands in derogation of the public's 'right to every man's evidence' and as 'an obstacle to the investigation of the truth,' [and] thus, ... '[i]t ought to be strictly confined within the narrowest possible limits consistent with the logic of its principle."').

33. Cavallaro v. United States, 284 F.3d 236, 245 (1 st Cir. 2002) (quoting United States v. Arthur Young \& Co., 465 U.S. 805, 816 (1984)) ("[T] he doctrine of construing the privilege narrowly . . has particular force in the context of IRS investigations given the "congressional policy choice in favor of disclosure of all information relevant to a legitimate IRS inquiry."').

34. Comcast, 901 N.E.2d at 1195.

35. In re Reorganization of Elec. Mut. Liab. Ins. Co., 681 N.E.2d 838, 841 (Mass. 1997). See also In re Grand Jury Subpoena (Zerendow), 925 F. Supp. 849, 854 (D. Mass. 1995); Resolution Trust Corp. 
A voluntary disclosure of the content of a privileged attorney communication constitutes waiver of the privilege as to all other such communications on the same subject. ${ }^{36}$ If the contents of a document or communication become public, the confidentiality and privilege are destroyed.$^{37}$ Accordingly, a disclosure of attorney-client communication to an accountant will undermine and may waive the attorney-client privilege. ${ }^{38}$

\section{B. Work-Product Doctrine}

The work-product doctrine is a codified law under the federal rules of civil procedure, ${ }^{39}$ which was first recognized by the Supreme Court in Hickman v. Taylor. ${ }^{40}$ The work-product doctrine enhances the litigation system by insulating attorney's work from intrusions, inferences, or borrowings by other parties. ${ }^{41}$ This doctrine "underpins our adversarial justice system" and permits lawyers to prepare for litigation without fear that their work product and mental impressions will be revealed to adversaries. ${ }^{42}$ The purpose of the work-product doctrine is to establish a "zone of privacy for strategic litigation planning" and to prevent one party from piggybacking on

v. Dean, 813 F. Supp. 1426, 1428 (D. Ariz. 1993) (“[I]n order to establish the applicability of the attorneyclient privilege to a given communication, the party asserting the privilege must affirmatively demonstrate non-waiver of the privilege."); Colonial Gas Co. v. Aetna Cas. \& Sur. Co., 144 F.R.D. 600, 604 (D. Mass. 1992); Murl A. Larkin, Federal Testimonial Privileges, $\S 2.05$ n.156, at 2-114 to 115 (1997).

36. United States v. Bump, 605 F.2d 548, 551 (10th Cir. 1979); Horowitz, 482 F.2d at 81; United States v. Cote, 456 F.2d 142, 144-45 (8th Cir. 1972); United States v. Aronoff, 466 F. Supp. 855, 860-62 (S.D.N.Y. 1979); In re Grand Jury Subpoena, 438 F. Supp. 1176, 1177-78 (S.D.N.Y. 1977); Handgards, Inc. v. Johnson \& Johnson, 413 F. Supp. 926, 929 (N.D. Cal. 1976); Haymes v. Smith, 73 F.R.D. 572, 576-77 (W.D.N.Y. 1976); Duplan Corp. v. Deering Milliken, Inc., 397 F. Supp. 1146, 1161, 1191 (D.S.C. 1974); ITT Corp. v. United Telephone of Florida, 60 F.R.D. 177, 185-86 (M.D. Fla. 1973).

37. See Wigmore, supra note 14, at $\S 2325$. But see In re Reorganization of Elec. Mut. Liab. Ins. Co., 681 N.E.2d 838, 841 (Mass. 1997) ("[T] he modern trend, however, has moved toward a principle that the privileged status of a communication or document is not lost when an attorney and client take reasonable precautions to ensure confidentiality but, for example, a privileged communication is nonetheless overheard."); Smith v. Armour Pharmaceutical Co., 838 F. Supp. 1573, 1576 (S.D. Fla. 1993).

38. United States v. Ackert, 169 F.3d 136, 139 (2d Cir. 1999).

39. Fed. R. Civ. P. 26(b)(3) (providing in relevant parts that "a party may not discover documents and tangible things that are prepared in anticipation of litigation or for trial by or for another party or its representative (including the other party's attorney, consultant, surety, indemnitor, insurer, or agent). But, subject to Rule 26(b)(4), those materials may be discovered if: (i) they are otherwise discoverable under Rule 26(b)(1); and (ii) the party shows that it has substantial need for the materials to prepare its case and cannot, without undue hardship, obtain their substantial equivalent by other means.”).

40. Hickman v. Taylor, 329 U.S. 495, 500 (1947).

41. Id. at 511 .

42. Mathis, supra note 18. 
another party's preparation ${ }^{43}$ by protecting attorney's written materials and mental impressions. ${ }^{44}$ The doctrine includes on-going litigation and litigation that is to be reasonably anticipated in the near future. ${ }^{45}$

A party asserting the work-product privilege has the burden of proof in establishing that the protected documents were prepared in anticipation of litigation. ${ }^{46}$ The phrase "in anticipation of litigation" has been subject to various interpretations. As a result, two main tests have developed: first, whether the documents protected by the work-product privilege were prepared "primarily or exclusively to assist in litigation," and second, whether the documents were prepared "because of" existing or expected litigation. ${ }^{47}$ The first test would potentially exclude documents containing analysis of expected litigation, if their primary, ultimate, or exclusive purpose is to assist in making the business decision. ${ }^{48}$ The second test includes documents, despite the fact that their purpose is not to "assist in" litigation. ${ }^{49}$ The "because of" formulation states that documents are considered to be prepared in the anticipation of litigation if "in light of the nature of the document and the factual situation in the particular case, the document can fairly be said to have been prepared or obtained because of the prospect of litigation." 50

The documents are not protected if they were created for non-litigation purposes. ${ }^{51}$ Thus, when determining whether a particular document should be withheld from discovery production, one should look to the function that document serves. ${ }^{52}$ After the burden is satisfied, it shifts to the other party to demonstrate a substantial need for the requested information. ${ }^{53}$

43. United States v. Adlman, 68 F.3d 1495, 1501 (2d Cir. 1995) (citing United States v. Nobles, 422 U.S. 225, 238 (1975)).

44. Hickman, 329 U.S. at 510.

45. Ward v. Peabody, 405 N.E.2d 973, 980 (Mass. 1980).

46. In re Powerhouse Licensing, LLC, 441 F.3d 467, 473 (6th Cir. 2006).

47. United States v. Adlman, 134 F.3d 1194, 1198 (2d Cir. 1998).

48. Id. See also In re Kidder Peabody Sec. Litig., 168 F.R.D. 459, 462, 466 (S.D.N.Y. 1996); Bowne v. AmBase Corp., 150 F.R.D. 465, 471 (S.D.N.Y. 1993); Martin v. Valley Nat'l Bank of Ariz., 140 F.R.D. 291, 304 (S.D.N.Y. 1991).

49. Adlman, 134 F.3d at 1198.

50. Charles Alan Wright, Arthur R. Miller \& Richard L. Marcus, 8 Federal Practice \& Procedure $§ 2024$, at 343 (1994). See In re Grand Jury Proceedings, 604 F.2d 798, 803 (3d Cir. 1979); National Union Fire Ins. Co. v. Murray Sheet Metal Co., Inc., 967 F.2d 980, 984 (4th Cir. 1992); Binks Mfg. Co. v. Nat'1 Presto Indus., Inc., 709 F.2d 1109, 1118-19 (7th Cir. 1983); Simon v. G.D. Searle \& Co., 816 F.2d 397, 401 (8th Cir. 1987), cert. denied, 484 U.S. 917 (1987); Senate of Puerto Rico v. United States Dep't of Justice, 823 F.2d 574, 586 n.42 (D.C. Cir. 1987).

51. United States v. Roxworthy, 457 F.3d 590, 595 (6th Cir. 2006).

52. Id. (citing Coastal States Gas Corp. v. Dep't of Energy, 617 F.2d 854 (D.C. Cir. 1980)).

53. United States v. Textron Inc. \& Subsidiaries, 507 F. Supp. 2d 138, 149 (D.R.I. 2007), aff'd in 
The work-product doctrine's protection may be overcome if the party seeking discovery can demonstrate a substantial need for materials and is unable to obtain the equivalent materials by other means without an undue hardship. ${ }^{54}$ The standard for such disclosure is either absolute or heightened and is only appropriate in rare or extremely unusual circumstances. ${ }^{55}$ However, the disclosure is limited because the courts protect against disclosure of attorney's or attorney's representatives mental impressions, conclusions, opinions, or legal theories.$^{56}$ Attorney's opinion work product is afforded greater protection than fact work product. ${ }^{57}$

There are multiple circumstances where the work-product doctrine does not apply. For instance, the work-product doctrine will be ineffective if the asserted privileged materials and documents are simply "funneled" through an attorney to create protection. ${ }^{58}$ The work-product doctrine does not insulate documents that are prepared in the ordinary course of a client's business. ${ }^{59}$ The work-product doctrine is also inapplicable if the documents would have been routinely created irrespective of the litigation. ${ }^{60}$ The doctrine does not apply to documents utilized in the analysis of bringing a company's financial books into conformity with Generally Accepted Accounting Principles. ${ }^{61}$ Further, the doctrine does not apply to an attorney's preparation of corporate documents or other materials in the ordinary course of business. ${ }^{62}$

part, 553 F.3d 87 (1 st Cir. 2009) (“The burden of establishing 'substantial need' rests on the party seeking to overcome the privilege.").

54. Comcast, 901 N.E.2d at 1202.

55. Id.

56. Id.

57. In re Grand Jury Subpoena, 220 F.R.D. 130, 145 (D. Mass. 2004).

58. Sneider v. Kimberly-Clark Corp., 91 F.R.D. 1, 4 (N.D. Ill. 1980) (“[T]he courts will not permit the corporation to merely funnel papers through the attorney in order to assert the privilege."). See also Radiant Burners, Inc. v. Am. Gas Ass'n., 320 F.2d 314, 324 (7th Cir. 1974) ("[T] he privilege would never be available to allow a corporation to funnel its papers and documents into the hands of its lawyers for custodial purposes and thereby avoid disclosure.").

59. United States v. Textron Inc. \& Subsidiaries, 577 F.3d 21, 25 (1st Cir. 2009) (citing Maine v. United States Dep't of the Interior, 298 F.3d 60, 70 (1st Cir. 2002) (quoting United States v. Adlman, 134 F.3d 1194, 1202 (2d Cir. 1998))). See also In re Grand Jury Proceedings, 601 F.2d 162, 171 (5th Cir. 1979) ("An attorney may not be used to insulate records an individual previously has prepared for his business. Thus, if an attorney instructs his client to deliver to the lawyer documents previously created by the client, those documents are not attorney work product, nor are they protected by the attorney-client privilege.").

60. Textron, 577 F.3d at 25 (citing Maine v. United States Dep't of the Interior, 298 F.3d 60, 70 (1st Cir. 2002) (quoting United States v. Adlman, 134 F.3d 1194, 1202 (2d Cir. 1998))).

61. United States v. El Paso Co., 682 F.2d 530, 543 (5th Cir. 1982).

62. Textron, 577 F.3d at 31 . 


\section{Accountant-Client Privilege}

In contrast to the attorney-client privilege, there is no confidential accountant-client privilege under federal or common law. ${ }^{63}$ Accordingly, if litigation involves "federal question" jurisdiction or a federal administrative proceeding, the accountant-client privilege will not be recognized. ${ }^{64}$ In diversity jurisdiction cases, where state laws may be applied thus creating choice of law issues, courts have to decide whether to apply state statutes that permit accountant-client privilege or follow the common law approach. ${ }^{65}$

Currently, eleven states recognize accountant-client privilege under their state laws. ${ }^{66}$ The general purpose of the accountant-client privilege is "to encourage people to make use of professional accounting services and to be frank and candid with such professionals." ${ }^{67}$ The accountant-client privilege is strictly construed because it has not been recognized under the common law. ${ }^{68}$ The privilege belongs to the client and not the accountant, ${ }^{69}$ which allows the client to waive the privilege when acting inconsistent with its assertion. ${ }^{70}$

63. Cavallaro, 284 F.3d at 246. See United States v. Arthur Young \& Co., 465 U.S. 805 (1984) (citing Couch v. United States, 409 U.S. 322, 335 (1973)). See also United States v. Arthur Andersen \& Co., 623 F.2d 725, 729 (1st Cir. 1980) (declining to depart from Couch's general rule); Mark A. Segal, Accountants and the Attorney-Client Privilege: In the Future, Privilege May Apply to a New and Broader Range of Situations, J. Acct., Apr. 1997, http://www.journalofaccountancy.com/Issues/1997/Apr/ segal.htm.

64. Francis M. Dougherty, Privileged Communication Between Accountant and Client, 33 A.L.R. 4th $539, \S 2$ (b) (2009).

65. $I d$.

66. Id. (noting the following states recognize accountant-client privilege: Arizona, Colorado, Florida, Georgia, Illinois, Indiana, Kansas, Louisiana, Maryland, New Mexico, and Pennsylvania). See also David E. Funkhouser III, Whose Right Is It Anyway: Arizona's Statutory Accountant-Client Privilege, MARICOPA L., Jan. 2006, http://www.quarles.com/docs/Client\%20Privilege.pdf.

67. Zepter v. Dragisic, 237 F.R.D. 185, 189 (N.D. Ill. 2006).

68. United States v. Bowman, 358 F.2d 421, 423 (3d Cir. 1966); Sansom Refining Co. v. Bache Halsey Stuart Shields, Inc., 92 F.R.D. 440, 441 (E.D. Pa. 1981); Rubin v. Katz, 347 F. Supp. 322, 324 (E.D. Pa. 1972).

69. Emtec, Inc. v. Condor Tech. Solutions, Inc., No. 97-6652, 1998 WL 242603, at *2 (E.D. Pa. May 14, 1998).

70. Id. 


\section{Tax Practitioner Privilege}

The Internal Revenue Code ("IRC") Section 7525 extends the commonlaw attorney-client privilege for communications with federal tax practitioners. ${ }^{71}$ Specifically, tax practitioner privilege applies to communication between a taxpayer and any federally authorized tax practitioner to the extent the communication would be considered a privileged communication if it were between a taxpayer and an attorney. ${ }^{72}$ The tax practitioner is defined as any individual who is authorized under federal law to practice before the IRS. ${ }^{73}$

Similar to others, this privilege contains multiple limitations. The privilege may only be asserted in non-criminal tax matters before the IRS ${ }^{74}$ and non-criminal tax proceedings in a federal court brought by or against the United States. ${ }^{75}$ The privilege does not apply to communications regarding tax shelters. ${ }^{76}$ Section 7525 also does not protect work product, ${ }^{77}$ and can be waived in the same matter as the attorney-client privilege. Although the Section 7525 privilege does not protect communications between the tax practitioner and client simply for preparation of a tax return, ${ }^{78}$ it does apply to communications for tax planning advice ${ }^{79}$ or an opinion letter. ${ }^{80}$ Akin to the attorney-client privilege, the Section 7525 privilege must be construed narrowly. ${ }^{81}$

71. See I.R.C. $§ 7525$ (2004) (noting this privilege is effective to communications made on or after July 22, 1998).

72. Id. at $\S 7525(\mathrm{a})(1)$. See Valero Energy Corp. v. United States, 569 F.3d 626, 628-29 (7th Cir. 2009); United States v. BDO Seidman, No. 02C4822, 2003 U.S. Dist. LEXIS 1634 (N.D. Ill. Feb. 3, 2003) (noting that $\S 7525$ allows for identity of the client privilege).

73. I.R.C. $\$ 7525(\mathrm{a})(3)(\mathrm{A})$.

74. See id. $\S 7525(\mathrm{a})(2)(\mathrm{A})$.

75. See id. § 7525(a)(2)(B).

76. See id. § 7525(b); United States v. BDO Seidman, 337 F.3d 802 (7th Cir. 2003).

77. United States v. Frederick, 182 F.3d 496, 500-02 (7th Cir. 1999).

78. United States v. KPMG LLP, 237 F. Supp. 2d 35, 39 (D.D.C. 2002).

79. BDO Seidman, 2003 U.S. Dist. LEXIS 1634, at *1-2.

80. Long-Term Capital Holdings v. United States, 3:01-CV-1290, 2002 U.S. Dist. LEXIS 23224, at $* 15$ (D. Conn. Oct. 30, 2002).

81. BDO Seidman, 2003 U.S. Dist. LEXIS 1634, at*10. 


\section{Accountant's Communications with Attorneys}

A disclosure of attorney-client communication to a third party, such as an accountant, generally undermines the attorney-client privilege. ${ }^{82}$ Communication between an attorney and an accountant does not become protected by attorney-client privilege simply because the communication proves to be important to the attorney's ability for client's representation. ${ }^{83}$ However, an exception known as the derivative attorney-client privilege, also referred to as the Kovel doctrine, allows for attorney-client privilege protection. ${ }^{84}$

The Kovel doctrine shields communications of third parties, such as accountants, hired to facilitate communication between attorneys and clients. ${ }^{85}$ The Kovel doctrine generally extends the attorney-client privilege and protects communications of accountants to facilitate communication between attorney and client, thus assisting the attorney in rendering legal advice to the client. ${ }^{86}$ Further, the inclusion of accountants in attorney-client communications does not destroy the privilege if the purpose of the third party's participation is to improve the comprehension of the communications between attorney and client. $^{87}$

The court in Kovel stressed that today's complexities prevent attorneys from effectively handling client's affairs without help of others. ${ }^{88}$ The court stated that the presence of an accountant while the client is relating a complicated tax fact pattern to an attorney should not compromise the attorney-client privilege any more than a linguist helping with a translation

82. Comcast, 901 N.E.2d at 1196.

83. Ackert, 169 F.3d at 139. See also Colton v. United States, 306 F.2d 633, 639 (2d Cir. 1962); Hickman, 329 U.S. at 508.

84. Kovel, 296 F.2d at 920-21. The Kovel doctrine has deep roots in Massachusetts jurisprudence. See Hanover Ins. Co. v. Rapo \& Jepsen Ins. Servs., Inc., 449 Mass. 609, 616 (2007) (explaining privilege protects "statements made to or shared with necessary agents of the attorney or the client, including experts consulted for the purpose of facilitating the rendition of such advice"); Foster v. Hall, 29 Mass. 89, 94 (1831) (noting privilege extends to communications with agents of attorney who are "necessary to secure and facilitate the communication between attorney and client").

85. Kovel, 296 F.2d at 918. See also Edwards, supra note 12, at 37; Segal, supra note 63 (noting that as a result of Kovel, attorney-client privilege to accountants can apply when: an attorney-client relationship exists, the accountant is retained by the attorney, the accountant renders services that abet the provisions of legal services, and the parties do not waive the privilege).

86. Comcast, 901 N.E.2d at 1196 (citing Kovel, 296 F.2d at 922).

87. Ackert, 169 F.3d at 139.

88. Kovel, 296 F.2d at 921. 
when the client speaks a different language than attorney. ${ }^{89}$ The premise is that, even to an attorney, the U.S. tax laws can often seem as incomprehensible as a foreign language..$^{90}$ Often the accountant's presence is "necessary," if not essential, for effective communication between the attorney and the client, which the attorney-client privilege was designed to protect. ${ }^{91}$ The "necessary" element means more than simply useful and convenient. ${ }^{92}$ Further, the courts have stated that the accountant's presence must have been nearly "indispensable" or serve "some specialized purpose" in communication between client and attorney. ${ }^{93}$ The courts interpreted the Kovel doctrine narrowly, ${ }^{94}$ and have rejected its application in circumstances where an attorney's ability to represent a client was only substantially improved by the accountant's presence and assistance. ${ }^{95}$

Following the creation of the Kovel doctrine, additional case law substantially restricted its original breadth. For instance, for the Kovel doctrine to be applicable, the client must seek privilege for legal advice and not accounting services. ${ }^{96}$ The doctrine begins to apply only after the law firm has retained the accountant. ${ }^{97}$ Thus, client's communications with an accountant prior to law-firm accountant engagement are not protected by the Kovel doctrine. ${ }^{98}$ Further, if the client seeks the accountant's advice rather than the lawyer's, attorney-client privilege does not exist..$^{99}$ The Kovel doctrine

89. Comcast, 901 N.E.2d at 1196 (citing Kovel, 296 F.2d at 922).

90. Kim J. Gruetzmacher, Comment, Privileged Communications with Accountants: The Demise of United States v. Kovel, 86 Marq. L. Rev. 977, 982 (2003).

91. Comcast, 901 N.E.2d at 1196 (citing Kovel, 296 F.2d at 922).

92. Cavallaro v. United States, 284 F.3d 236, 249 (1st Cir. 2002).

93. Id.

94. Black \& Decker Corp. v. United States, 219 F.R.D. 87, 90 (D. Md. 2003) (“Cases decided after Kovel have narrowly interpreted this concept of derivative privilege.").

95. Ackert, 169 F.3d at 139 (" [A] communication between an attorney and a third party does not become shielded by the attorney-client privilege solely because the communication proves important to the attorney's ability to represent the client."); United States v. Chevron Texaco Corp., 241 F. Supp. 2d 1065, 1071 (N.D. Cal. 2002) ("The interpreter analogy and the statement that the accountant is needed to facilitate the client's consultation both strongly indicate that Kovel did not intend to extend the privilege beyond the situation in which an accountant was interpreting the client's otherwise privileged communications or data in order to enable the attorney to understand those communications or that client data."); In re G-I Holdings Inc., 218 F.R.D. 428, 434 (D.N.J. 2003) (noting the Kovel privilege is limited to "when the accountant functions as a 'translator' between the client and the attorney").

96. Comcast, 901 N.E.2d at 1196 (citing Kovel, 296 F.2d at 922).

97. In re Grand Jury Proceedings Under Seal, 947 F.2d 1188, 1190-91 (4th Cir. 1991); United States v. Cote, 326 F. Supp. 444, 449-50 (D. Minn. 1971).

98. Gruetzmacher, supra note 90, at 988 ("The privilege, if any, does not arise until after the accountant enters into a Kovel agreement with the law firm.").

99. Comcast, 901 N.E.2d at 1196 (citing Kovel, 296 F.2d at 922). See Olender v. United States, 210 
only applies to situations where the accountant works as a translator of information from client to attorney. ${ }^{100}$ Thus, as a result of these numerous limitations, the general concept of the Kovel doctrine is now highly limited and littered with exceptions. ${ }^{101}$

\section{Recent Developments}

The two recent cases of Commissioner v. Comcast Corp. and United States $v$. Textron put a new spin on the existing privilege law and its effects on the privileged communications between attorneys and accountants retained for the purposes of client representation in complex transactional tax and compliance matters.

\section{A. Comcast}

In Comcast, the Massachusetts Supreme Court addressed whether the attorney-client privilege or the work-product doctrine protects from disclosure communications between an in-house corporate counsel and outside tax accountants consulted for purposes of structuring a stock sale. ${ }^{102}$

In 1996, US West purchased Continental Cablevision ("Continental"). Continental, through a wholly owned subsidiary, Continental Teleport, Inc. ("Teleport"), owned $11.2 \%$ of the stock of Teleport Communications Group, Inc. ("TCG"). ${ }^{103}$ Upon acquisition, Continental Cablevision immediately merged into MediaOne, US West's wholly owned subsidiary. The Department of Justice filed a civil antitrust action against US West and Continental, which was settled on the premise that US West would divest all interest in TCG stock. ${ }^{104}$ US West created a new entity, Continental Holding Company ("Continental Holding"), dissolved Teleport on the same day, and simultaneously transferred Teleport's assets and TCG shares to Continental holding. ${ }^{105}$ Thereafter, US West divested itself of TCG shares in four separate

\footnotetext{
F.2d 795, 805-06 (9th Cir. 1954).

100. Ackert, 169 F.3d at 139; Calvin Klein Trademark Trust v. Wachner, 198 F.R.D. 53, 54 (S.D.N.Y. 2000)

101. Gruetzmacher, supra note 90 , at 994.

102. Comcast, 901 N.E.2d at 1188.

103. Id. at 1189 (noting that Continental and Teleport were Massachusetts corporations).

104. Id. (stating that the Feb. 28,1997 settlement required US West to first reduce its ownership of TCG common stock to less than 10 percent within four months, June 30,1997, and then completely divest of its interest in TCG by Dec. 31, 1998).

105. Id. at 1190 (noting that Continental Holding was formed under MASs. GEN. LaWs ch. $62, \S 8$
} 
transactions. Continental Holding reported a capital gain of nearly $\$ 500$ million from the sale of TCG shares on its federal tax return, but did not file a Massachusetts corporate excise tax return, claiming an exemption as a Massachusetts corporate trust. ${ }^{106}$ Under Massachusetts law, a corporate trust that qualifies as a holding company was exempt from state tax. ${ }^{107}$ Two years later, Continental Holding was dissolved and its assets were transferred to US West's successor. ${ }^{108}$

The stock transaction was likely to have substantial tax consequences for US West. ${ }^{109}$ Although US West's in-house counsel, Andrew Ottinger, was an experienced tax litigator, he was unfamiliar with Massachusetts tax law. ${ }^{110}$ Ottinger examined planning opportunities for the transaction, but needed the expertise of outside consultants to help him interpret Massachusetts state tax law. ${ }^{111}$ In particular, Ottinger was concerned that the Massachusetts Department of Revenue (DOR) would challenge the appropriateness of the transaction for US West's sale of TCG stock. ${ }^{112}$ Thus, prior to West's disposition of TCG stock, Ottinger sought the advice of tax professionals at Arthur Andersen (“Andersen"). ${ }^{113}$ Upon Ottinger's request, Andersen prepared a memorandum describing pros and cons, planning opportunities and possible litigation risks. ${ }^{114}$ At deposition, Andersen professionals who prepared the memorandum testified that they provided tax and planning advice, and not legal advice. ${ }^{115}$ However, Ottinger stated that he considered all communication with Andersen to be protected by attorney-client privilege and attorney work product. Ottinger took steps to ensure that Andersen's documents remained confidential and privileged by sending Andersen's documents to the separate

as a Massachusetts corporate trust)

106. Id. (stating that the capital gain reported by Continental Holding on its Dec. 31, 1997 tax return was $\$ 495,733,830$; Continental Holding claimed an exemption under MASs. GEN. Laws ch. 62 , § 8(b) for filing a Massachusetts corporate excise tax return).

107. Id. at 1190 n.10. See Mass. Gen. Laws AnN. ch. 62, § 8(b) (West. 2005) (repealed 2008).

108. Comcast, 901 N.E.2d at 1190.

109. Id. at 1191.

110. $I d$.

111. Id. (noting that Ottinger stated that he considered "various ways to set up the transaction, to determine the best, legitimate vehicle by which to deal with the tax consequences from the sale of [TCG] shares, and to assess the risks of litigation associated with the different vehicles").

112. Id. at 1189 .

113. Id. at 1190 .

114. Comcast, 901 N.E.2d at 1191.

115. Id. at $1191 \mathrm{n} .13$ (stating that one of the preparer's, Michael E. Porter III, was licensed to practice law, but was precluded from practicing law while employed by Andersen). 
and locked files of West's law department maintained for privileged documents. ${ }^{116}$

In 2000, the Massachusetts DOR commenced an audit examination of Comcast and its affiliates pertaining to the acquisition of Continental by US West. ${ }^{117}$ In particular, the DOR investigated whether Comcast and its affiliates failed to pay Massachusetts corporate excise taxes in connection with the forced liquidation of stock shares that resulted in approximately $\$ 500$ million in capital gains, ${ }^{118}$ as the Comcast's affiliate reported the gains on its federal tax return, but not on its Massachusetts corporate excise tax return. ${ }^{119}$ The commissioner claimed that there was no legitimate business or economic purpose for reorganizing Teleport into a Massachusetts corporate trust, Continental Holding, prior to the TCG stock sale. ${ }^{120}$

Pursuant to an administrative summons, the DOR's commissioner sought the production of documents which Comcast asserted were protected by the attorney-client privilege and work-product doctrine. ${ }^{121}$ The commissioner of the DOR challenged the applicability of privileges to six particular documents withheld by Comcast, including Andersen's different parts of drafts and the final memoranda prepared before the corporate reorganization. ${ }^{122}$ These

116. Id. at 1191 .

117. Id. at 1189 (stating that the Comcast Corporation (Comcast) is the successor company to AT\&T Broadband, which is successor to MediaOne Group, Inc. (MediaOne), which is the successor to US West, Inc. (US West)).

118. Id. at 1188 .

119. Id.

120. Comcast, 901 N.E.2d at 1192 (stating that the commissioner argued that if there was no legitimate business or economic purpose, the step transaction rule could be invoked, which would treat the series of separate transaction steps if such steps were in substance integrated, interdependent, and focused towards a particular result. Thus, if intermediate steps of the transaction had no legitimate purpose beyond tax avoidance, the step may be collapsed for tax purposes under the step transaction doctrine.). See also Gen. Mills, Inc. v. Comm'r, 795 N.E.2d 552 (Mass. 2003); Penrod v. Comm'r, 88 T.C. 1415, 1428 (1987); Comm'r v. Dupee, 670 N.E.2d 173 (Mass. 1996); Rev. Rul. 79-250, 1979-2 C.B. 156.

121. Comcast, 901 N.E.2d at 1188 (noting that the commissioner issued the administrative summons pursuant to MASs. GEN. LAws ch. $62 \mathrm{C}, \S 70$, which provides: " $[\mathrm{t}]$ he commissioner may take testimony and proofs under oath with reference to any matter within the official purview of the department of revenue, and in connection therewith may issue summonses and require the attendance and testimony of witnesses and the production of books, papers, records, and other data. Such summonses shall be served in the same manner as summonses for witnesses in criminal cases issued on behalf of the commonwealth, and all provisions of law relative to summonses in such cases shall, so far as applicable, apply to summonses issued hereunder. Any justice of the supreme judicial court or of the superior court may, upon the application of the commissioner, compel the attendance of witnesses, the production of books, papers, records, and other data, and the giving of testimony before the commissioner in the same manner and to the same extent as before the said courts.").

122. Id. at 1191-92 (stating that the commissioner originally sought production of all documents identified by Comcast in its privilege log. The commissioner sought the production of documents pertaining 
documents consisted of sixteen single-spaced pages of detailed stock sale analysis under application of Massachusetts law. ${ }^{123}$

The commissioner requested the Superior Court to compel production of documents that Comcast claimed as privileged. ${ }^{124}$ However, the court denied the commissioner's motion holding that Andersen's memoranda were protected by attorney-client privilege because they contained detailed analysis of Massachusetts tax law and provided information necessary for effective client representation. ${ }^{125}$ Further, the court held that the memoranda were protected by the work-product doctrine because they were prepared in anticipation of litigation. ${ }^{126}$ The Massachusetts Supreme Court on its own initiative transferred the case from the Massachusetts Court of Appeals.

1. The Advice Rendered by Andersen's Accountants to Comcast Was Not Protected by the Attorney-Client Privilege

On appeal to the Massachusetts Supreme Court, the commissioner argued that Comcast did not meet its burden in establishing that attorney-client privilege applied, for three reasons: (1) Comcast did not submit any proof that the Andersen memoranda contained confidential communication from the client; ${ }^{127}$ (2) the Andersen memoranda did not fall within the derivative privilege; ${ }^{128}$ and (3) the Superior Court improperly expanded the privilege where narrow construction was required. ${ }^{129}$

The court disagreed with the commissioner's first argument that the US West sale of Continental's stake in TCG or the US West restructuring of Teleport were not confidential. ${ }^{130}$ It concluded that the commissioner's first

to the TCG stock sale, including documents relating to Teleport reorganization into Continental Holding. Generally, Comcast produced various responsive documents, but withheld Andersen's memorandums under the attorney-client privilege and work-products doctrine. The six requested documents are identified as follows: first draft of the Andersen memorandum, two identical documents that appear to be the second draft of memorandum, two identical documents to the second draft of memorandum but each missing its first page, and the final version of memorandum.).

123. Id. at 1192 .

124. $I d$. at 1193 (noting that the commissioner requested all documents listed on Comcast's privilege $\log$ and all unredacted versions of redacted documents).

125. Id.

126. Id. (noting that the Superior Court also denied commissioner's subsequent motions for reconsideration).

127. Comcast, 901 N.E.2d at 1195 (referencing communication from US West to Ottinger).

128. Id. See Kovel, 296 F.2d at 918 (recognizing the derivative privilege).

129. Comcast, 901 N.E.2d at 1196.

130. Id. 
argument was based on the incorrect assertion that attorney-client privilege applies only where the client's information that is the subject of the communication is confidential. The court held that Ottinger intended and took adequate steps to keep the communications with Andersen confidential and that Andersen received from counsel private information about US West's disposition of TCG stock. ${ }^{131}$

The commissioner's second argument that derivative privilege did not apply to Comcast's documents was based on two assertions. First, the commissioner argued that the derivative privilege only applies where accountant's services are necessary to translate or interpret documents to facilitate attorney's understanding in order to render requested legal advice. ${ }^{132}$ Second, the commissioner argued that derivative privilege did not apply since US West sought professional tax advice and not legal advice of an attorney. ${ }^{133}$ Although the court recognized the difficulty of providing a clear distinction between legal, tax, or accounting advice, the court sided with the commissioner's argument that advice rendered by Andersen was not covered by the attorney-client privilege. ${ }^{134}$ The court stated that advice provided by Andersen's accountants was not covered by the attorney-client privilege, derivative or otherwise. ${ }^{135}$ Further, the court stated that since Ottinger sought the tax advice from an Andersen accountant, and not lawyers, the attorneyclient privilege did not apply. ${ }^{136}$ Accordingly, the court held that the attorneyclient privilege did not protect communications between Ottinger and Andersen's accountants. ${ }^{137}$

\section{Work-Product Doctrine Saves Comcast's Documents from Disclosure}

The court also had to determine whether the work-product doctrine's protection was applicable to the Andersen's memoranda-litigation analysis

131. Id.

132. Id. at 1197 .

133. $I d$.

134. Id. at 1200 .

135. Comcast, 901 N.E.2d at 1200.

136. $I d$.

137. Sheldon H. Laskin, The Attorney Work Product Decision in Comcast, a MA Tax Practice Insight, 2009 EMERGING IsSUES 3540 (Apr. 23, 2009), available at LEXIS ("In this case, Ottinger did not consult Andersen so that Andersen could translate or interpret US West's proposed transaction. Instead, Ottinger consulted Andersen so that Andersen could render advice as to whether the proposed transaction would be subject to Massachusetts tax. The Court ruled this consultation does not come within the Kovel rule. Therefore, Ottinger's communication to Andersen waived the attorney-client privilege."). 
prepared by accountants to inform a business decision which turns on party's assessment of the likely litigation outcome expected to result from the transaction. ${ }^{138}$ The commissioner argued that memoranda prepared by Andersen do not meet the "because of" test because they were prepared to "avoid the prospect of litigation" and because Ottinger failed to demonstrate a specific prospect of litigation. ${ }^{139}$

The court applied the "because of" test and disagreed with the commissioner's contentions. It relied on the Adlman decision, which stated that work-product doctrine extends to litigation analysis prepared to facilitate a party's informed business decision process. ${ }^{140}$ The court held that based on a review of Andersen's retention and consequently created memoranda, the documents were prepared or obtained because of the prospect of litigation. ${ }^{141}$ The evidence considered, such as Ottinger's affidavit, showed there was a reasonable possibility that the Massachusetts DOR would challenge the transaction in light of substantial gains recognized by US West during the divestment of TCG shares, thus requiring a discussion and business planning to prepare for possible future litigation. ${ }^{142}$ The court stated that Andersen's memoranda would not have been "prepared irrespective of prospect of litigation"143 and were created "because of" a reasonable possibility of litigation with the DOR. ${ }^{144}$ Further, the court stated that Andersen's memoranda constituted opinion work product as they contained mental impressions, conclusions, opinions, or legal theories, and the commissioner had failed to satisfy the burden of demonstrating "extremely unusual" circumstances to overcome the protection of the work-product doctrine. ${ }^{145}$ Accordingly, the court stated that even though the Andersen memoranda were not protected by the attorney-client privilege, they were protected by the workproduct doctrine. ${ }^{146}$ 1998)).

138. Comcast, 901 N.E.2d at 1203 (citing United States v. Adlman, 134 F.3d 1194, 1197 (2d Cir.

139. Id. at 1204-05 (noting that the commissioner argued that the Andersen memoranda did not "meet that test because they were prepared to 'avoid the prospect of litigation,' and because ... Ottinger's 'conclusory assertions fall far short of demonstrating a specific prospect of litigation"').

140. Id. at 1205 (citing United States v. Adlman, 134 F.3d 1194, 1197 (2d Cir. 1998)).

141. $I d$.

142. $I d$.

143. Id. (citing United States v. Textron, Inc., 553 F.3d 87, 95 (1st Cir. 2009)).

144. Comcast, 901 N.E.2d at 1205 (citing Ward v. Peabody, 405 N.E.2d 973 (1980)).

145. $I d$.

146. Id. 


\section{B. Textron}

In Textron, the main issue for the court to decide was whether the attorney work-product doctrine shields from IRS summons "tax accrual work papers" prepared by lawyers and other professionals in Textron's in-house tax department to support Textron's calculation of tax reserves for its audited corporate financial statements. ${ }^{147}$ The IRS defines tax accrual work papers as audit work papers that were prepared by the taxpayer, the taxpayer's accountant, or the independent auditor and that relate to the tax reserve for current, deferred and potential or contingent tax liabilities. ${ }^{148}$ However, the documents that constitute the corporation's tax accrual work papers may vary from case to case. ${ }^{149}$ These tax accrual work papers can "pinpoint the soft spots on a corporation's tax return by highlighting those areas in which the corporate taxpayer has taken a position that may, at some later date, require the payment of additional taxes."150

Textron is a publicly-traded company and a major aerospace and defensive conglomerate with over 100 subsidiaries, which is regularly audited by the IRS. ${ }^{151}$ Textron is required by federal securities law to have its public financial statements certified by an independent auditor. ${ }^{152}$ The preparation of the financial statements requires Textron to calculate reserves to be entered on its books to account for any contingent tax liabilities, which include estimates of potential liability if the IRS challenges Textron's position on the tax return. ${ }^{153}$ The calculation of reserves includes preparation of work papers

147. United States v. Textron, Inc., 577 F.3d 21, 22 (1st Cir. 2009). See above comment regarding the Textron case.

148. Internal Revenue Serv., Internal Revenue Manual pt. 4, ch. 10, 20 (2004), available at http://www.irs.gov/irm/part4/irm_04-010-020.html\#d0e46 ("These workpapers reflect an estimate of a company's tax liabilities and may also be referred to as the tax pool analysis, tax liability contingency analysis, tax cushion analysis, or tax contingency reserve analysis .... The name given the workpapers by the taxpayer, the taxpayer's accountant, or the independent auditor is not determinative.").

149. United States v. Textron, Inc., 507 F. Supp. 2d 138, 142 (D.R.I. 2007) (stating that "because there is no immutable definition of the term 'tax accrual workpapers,' the documents that make up a corporation's 'tax accrual workpapers' may vary from case to case"). See Steve R. Johnson, The Work Product Doctrine and Tax Accrual Workpapers, 124 TAX Notes 155 (2009) (stating that definitional issues arise "because [1] companies have different types of potential tax exposure, [2] companies organize their records in different ways, [3] companies' accountants may have different needs or prefer different types and formats of material, [and 4] companies differ in how they use in-house and outside counsel in preparing or review tax analyses").

150. Arthur Young, 465 U.S. at 813.

151. Textron, 577 F.3d at 22.

152. Id. See 15 U.S.C. $\S \S 78(1), 78(\mathrm{~m})(2006) ; 17$ C.F.R. $\S 210$ (2009).

153. Textron, 577 F.3d at $22-23$ (stating that contingent tax liabilities affect portrayal of assets and 
which describe Textron's potential liabilities for future taxes and explain calculations to the certifying independent auditor. ${ }^{154}$ Textron's tax department lists the tax return items that the IRS may challenge resulting in additional taxes and percentage estimates of the IRS's chances of successful challenge. ${ }^{155}$ Calculations are conducted to fix the reserve amount, which is entered on the books for certain tax items. ${ }^{156}$ The result of all calculations is the reported total reserve figure. ${ }^{157}$

Although the IRS does not automatically request tax accrual work papers from taxpayers, the IRS seeks these documents where it has concluded that the taxpayer had engaged in certain listed transactions. ${ }^{158} \mathrm{~A}$ listed transaction is a transaction that the IRS has determined to be a tax avoidance transaction and is identified by notice, regulation, or other form of published guidance. ${ }^{159} \mathrm{In}$ 2003, the IRS audited Textron's corporate taxes for 1998-2001 and determined from Textron's 2001 tax return that Textron's subsidiary, Textron Financial Corp. ("Textron Financial"), had engaged in nine listed transactions known as sale-in lease-out ("SILO”) transactions. ${ }^{160}$

To determine the accuracy of Textron's tax return, the IRS issued an administrative summons, which allows the IRS to examine any books, papers, records, or other data, which may be relevant or material to IRS inquiry. ${ }^{161}$ The administrative summons further requested work papers created by Textron's outside accounting firm in determining the adequacy of Textron's

earnings).

154. Id. at 23 .

155. Id.

156. Id. (stating that spreadsheet calculations of reserves may be supported by various emails or notes).

157. Id. ("A company's published financial statements do not normally identify the specific tax items on the return that may be debatable but incorporate or reflect only the total reserve figure.").

158. Id.

159. 26 C.F.R. $\S 1.6011-4(b)(2)(2009)$.

160. Textron, 577 F.3d at 23-24 (stating that Textron Financial purchased equipment from a foreign utility or transit operator and leased the equipment back to the seller on the same day. Although the SILO transaction is considered legitimate, the IRS identifies it as a listed transaction. SILO transactions allow taxexempt or tax-indifferent organizations (ex. city-owned transit authority) to transfer depreciation and interest deductions from which they cannot benefit to other taxpayers, who may use them to shelter their income from taxation. In SILO transactions where the sole motive is tax avoidance, the IRS may disregard the transaction and assess taxes on the wrongfully sheltered income.). See AWG Leasing Trust v. United States, 592 F. Supp. 2d 953, 958 (N.D. Ohio 2008).

161. Textron, 577 F.3d at 24 (noting that the administrative summons was issued pursuant to 26 U.S.C. $§ 7602$. The IRS policy directly requests all workpapers for the tax year in question where the taxpayer claims benefits from a multiple listed transaction.). See I.R.S. Announcement 2002-63, 2002-27 I.R.B. (July 8, 2002). 
tax reserves. ${ }^{162}$ Although Textron had provided such documents to its outside accounting firm, it refused to provide them to the IRS, which resulted in litigation. ${ }^{163}$ The contents of requested work papers included summary spreadsheets showing for each disputable item the amount in controversy, estimates of probability in percentage terms of IRS's successful challenge, calculated reserve amounts, back up email and notes. ${ }^{164}$ Some of the "litigation hazard percentage" estimates showed the IRS's success of prevailing during litigation at 100 percent. ${ }^{165}$

Revelation of these documents presented a significant concern for Textron, particularly because of those items with estimates of the IRS's probability of success in litigation at 100 percent. ${ }^{166}$ Armed with Textron's internal work papers specifying this litigation hazard percentage, the IRS would be able to immediately identify Textron's vulnerabilities and the specific amounts Textron should be willing to pay to settle each tax matter. ${ }^{167}$

Textron challenged the IRS summons arguing that it lacked a legitimate purpose and that information sought by the IRS was protected by the attorneyclient privilege, work-product doctrine, and tax practitioner privilege. ${ }^{168}$ Conversely, the IRS challenged all of Textron's claimed privileges. ${ }^{169}$ The district court denied the IRS's petition for enforcement of its administrative summons because of the work-product doctrine. ${ }^{170}$ However, the court noted that Textron-prepared work papers, which might have been protected by the attorney-client or tax practitioner privilege, lost their privilege protection when Textron disclosed the work papers to its outside accounting firm. ${ }^{171} \mathrm{On}$ an appeal, the district court's decision was upheld by a divided panel, but was subsequently overturned by the court sitting en banc. ${ }^{172}$

The First Circuit Court of Appeals held against Textron and stated that the work product privilege did not apply because work papers were independently required by statutory and audit requirements. ${ }^{173}$ The court stated

162. Textron, 577 F.3d at 24.

163. Id. (noting that Textron employed Ernst \& Young as an outside accounting firm).

164. Id. at 25 .

165. Id. But see id. at 36 (Torruella, J., dissenting).

166. Textron, 577 F.3d at 36 (Torruella, J., dissenting).

167. Id.

168. Id. at 24 .

169. $I d$.

170. Id. at 25 .

171. Id.

172. Textron, 577 F.3d at 26.

173. Id. 
that the work product privilege is intended to protect work done for litigation and not in preparing financial statements. ${ }^{174}$ The court reasoned that any experienced litigator would describe tax accrual papers as tax documents and not as materials prepared for litigation. ${ }^{175}$ The purpose of Textron's work papers was to make book entries, prepare financial statements and obtain an approval of an independent auditor. ${ }^{176}$ The tax work papers were prepared to determine if Textron was adequately reserved with respect to any future dispute or litigation. ${ }^{177}$ Even if litigation with the IRS was remote, Textron would still have to prepare work papers to support their calculations of the tax reserves. ${ }^{178}$ Accordingly, the tax reserve figures and accompanying calculations were created to support the financial statements and the independent audit. ${ }^{179}$

The court found additional auxiliary reasons to rule against Textron. It stated that "tax collection is not a game," even if Textron thinks the disclosure of its work papers and spreadsheets is "unfair." 180 It stressed that underpayment and avoidance of taxes threatens public interest in revenue collection. ${ }^{181}$ The court referenced that the same rules applied to the IRS in regards to their unprivileged information, which was equally subject to discovery rules and available to Textron. ${ }^{182}$ In summary, the court held that there was no evidence of Textron's work papers being unquestionably prepared for litigation. As a result, the appeals court vacated the district court's judgment and remanded it for further proceedings consistent with its decision. ${ }^{183}$

174. Id. at 30-31.

175. $I d$. at 28 .

176. Id. at 27.

177. Id. The testimony of Textron's director of tax reporting stated that the primary purpose in preparing tax reserve papers "was to determine whether Textron was adequately reserved with respect to any potential disputes or litigations that would happen in the future." Textron needed "to ensure that ... [it was] adequately reserved in the current year on Textron's financial statements." The director of tax agreed that as a publicly traded company Textron was required to file financial statements that include tax reserves with the Securities and Exchange Commission. Further, the director of tax stated Textron needed to support its determinations of tax reserves with evidence to satisfaction of independent auditors.

178. Textron, 577 F.3d at 28.

179. Id. at 30 .

180. Id. at 31 .

181. Id.

182. Id. n. 10 (citing Abel Inv. Co. v. United States, 53 F.R.D. 485, 488 (D. Neb. 1971)) (holding that IRS documents created during an audit were not protected work product, despite containing mental impression and legal theories of attorneys', because an IRS audit is not litigation).

183. Id. at 31-32. 


\section{Methods to Preserve Privileged Information After COMCAST AND TEXTRON}

For any practitioner it is critical that attorney-client, work-product, accountant-client, and tax practitioner privileges are not indivertibly waived. Although there is no strategy that will cover all circumstances, there are general procedures that attorneys may implement in their practice to preserve privilege.

First, it is important for attorneys to understand the purpose for which the documents are being created. ${ }^{184}$ The attorney must consider if the document is being prepared in the regular course of business, if it is being prepared in anticipation of litigation, or if the document has a dual purpose. The attorney must determine if the accountant's role will be to interpret the law, which under the Comcast opinion is not protected by attorney-client privilege, or whether to facilitate and interpret communication between attorney and client. ${ }^{185}$ After determining that the document was created or is being created for a privileged purpose, the attorney should engage into strategic planning to preserve that privilege.

Second, to protect confidentiality, the attorney working with accountants should send the accountant a formal letter establishing the scope and purpose of their relationship. ${ }^{186}$ If any advice is sought because the tax benefits may be contested in the future, it is essential that this is communicated from attorney to accountant at the start of representation, and the engagement letter requests tax advice in anticipation of the tax dispute. ${ }^{187}$ This will permit the attorney to establish the parameters of the accountant's work, define for which legal purpose the accountant's work will be utilized, and provide necessary supervision ensuring that any document preparation is a work product. ${ }^{188}$ Also, if the documents are being reviewed because of or primarily to assist the attorney in present or future litigation, this purpose should be communicated to the accountant in the engagement letter.

Third, to enhance the likelihood of preserving a privilege claim during litigation, all services provided by accountants should be documented as

184. Steven C. Bennett, Protecting Privileges When Working with Accountants, Prac. Litigator, Nov. 2009, at 37.

185. Id. at 13. See Comcast, 901 N.E.2d at 1198.

186. Bennett, supra note 184 , at 16 .

187. Cook, supra note 11 , at 37.

188. Bennett, supra note 184, at 16. 
thoroughly as possible. ${ }^{189}$ To strengthen the privilege claim, an accountant should perform only requested work in accordance with the scope of the attorney's written agreement. ${ }^{190}$ Attorney's engagement and presence during the entire period of the accountant's work will strengthen the argument that documents are privileged and are prepared in anticipation of litigation. ${ }^{191}$

Fourth, all privileged documents and materials should be labeled as privileged and should be treated as confidential to avoid any claims of waiver. ${ }^{192}$ A privilege $\log$ should also be created specifying the nature of the document and citing applicable privileges. ${ }^{193}$ Although labeling by itself will not protect a document and make it privileged per se, the implementation of clear standards for labeling of materials and work papers as work product prepared in anticipation of litigation is recommended. ${ }^{194}$ The work papers where the litigation is clearly anticipated and are considered hot-button issues for the taxing authorities should be separated from less sensitive tax documents in order to limit any potential disclosures. ${ }^{195}$ After separation, these documents should be retained and treated under appropriate confidentiality precautions, such as being indexed and held in a locked file space and specifying the purpose of the documents. ${ }^{196}$ Further, FIN 48 documentation should be further separated from all other files due to its sensitivity for tax liability exposure. ${ }^{197}$

Fifth, the attorney should review the external (independent) accountant's policies regarding document retention and extension of privilege to the rendered opinion. When a tax opinion from an outside accountant is produced it should clearly describe its purpose and application, whether it is confidential, if it was prepared for the purposes of anticipated litigation, and state for which purposes the opinion should be considered confidential. It is recommended that any external accountant should not be allowed to retain a copy of a company's transactional or tax accrual papers. ${ }^{198}$

Finally, it has been suggested that hiring an outside counsel in determining whether there is tax exposure is a good indication that there is a

189. Segal, supra note 63.

190. $I d$.

191. Pawlow \& Spencer, supra note 10, at 38.

192. Bennett, supra note 184 , at $15-16$.

193. Id. at 15 .

194. Roger Russell, Case Exposes Tax Workpapers to IRS, AcCT. TodAy, Oct. 5, 2009, at 12.

195. Id.

196. Cook, supra note 11 , at 37.

197. Id. at 38 .

198. Pawlow \& Spencer, supra note 10 , at 38. 
genuine concern for anticipated litigation. ${ }^{199}$ During the entire engagement with an accountant, the attorney must maintain and document all applicable documents to which privilege should be extended. ${ }^{200}$

As new case law develops, the companies and practitioners must reconsider their current practices and strategies, and adapt to the new standards in order to preserve their clients privileged documents and communications. The Comcast and Textron opinions exemplify that applicable privilege law continues to change and that attorneys, accountants, and tax practitioners must stay current in order to provide diligent services to their corporate clients.

\section{UNRESOLVED IsSUES}

The parameters of the attorney-client privilege, work-product doctrine, accountant-client privilege, and tax practitioner privileges have been continuously evolving and changing. The recent decisions of Comcast and Textron demonstrate that courts continue to narrow and limit privilege law as it is applied to complex tax transactions and tax documents. Consequently, today only limited privilege protection is recognized for attorney communications with accountants. ${ }^{201}$ Thus, the practitioners and their service providers, such as accountants, should be mindful of recent holdings in Comcast and Textron as they create materials for business and transactional purposes that may be subject to future litigation. ${ }^{202}$

The Comcast and Textron decisions also add additional uncertainty to an already vastly litigious area of the law. The courts have previously split interpretation of the phrase of "anticipation in litigation" between "primary purpose" and "because of" tests. ${ }^{203}$ According to Textron's dissenting opinion, Textron's holding proceeded to further split the application of the "because of" test while rejecting that test's protection for dual purpose documents and created a new test of "prepared for" use in litigation. ${ }^{204}$ Such differences of tests and standards make the practice of law and compliance not only difficult, but also unpredictable.

199. Id.

200. Bennett, supra note 184 , at 16 .

201. Gruetzmacher, supra note 90 , at 979.

202. Christian M. Hoffman \& Matthew C. Baltay, Maintaining Client Confidences: Developments at the Supreme Judicial Court and First Circuit in 2009, 53 B.B.J. 20, 23 (2009).

203. Textron, 577 F.3d at 33.

204. Id. at 33-34. 
Additionally, the Textron and Comcast decisions add uncertainty to corporate strategy and tax planning. Today, almost every business decision by a company has a legal dimension, which often requires attorneys to seek advice from outside accountants. The differences between the state and local laws and regulations make such communication a necessity not only as part of corporate due diligence process, but also as part of compliance with the law. Complicated scenarios also exist when documents have dual purpose of compliance or are being created in the regular course of business and prepared where litigation is also a possibility ${ }^{205}$ In states that recognize an accountantclient privilege, it is unknown if this privilege will protect client's private communications and documents when attorney-client privilege or workproduct doctrine become inapplicable. As the area of privileged communications law continues to remain uncertain and change, corporate attorneys and their clients cannot simply rely on the belief that their communications and documents will remain protected from discovery by the taxing authorities. ${ }^{206}$

The dissent in Textron urges the Supreme Court to intervene and clarify the current uncertainty present between the circuits. Such intervention is necessary and essential to the daily practice of litigators, ${ }^{207}$ accountants, tax practitioners, consultants, and corporate clients. It is unlikely that the courts could envision the difficulty their decisions would create on the current transactional and tax practice. Thus, unless clarity is provided, either through a Supreme Court decision or through federal legislation, privileged communications in complex tax and transactional matters will continue to be a highly unpredictable and uncertain area of the law, which can significantly affect corporate clients and their respective legal, accounting, and tax professionals. 